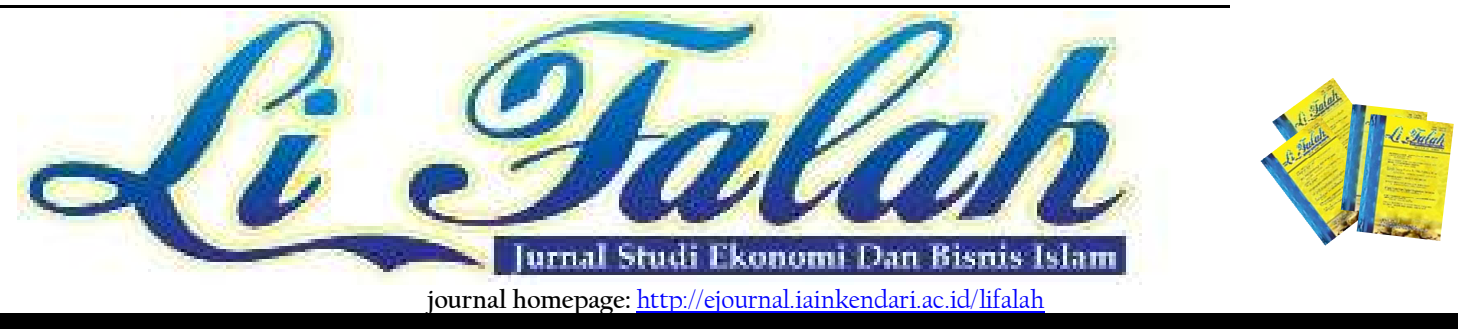

\title{
Dampak Variabel Makro Ekonomi Domestik dan Global Terhadap Indeks Saham Syariah Indonesia (ISSI) Periode Mei 2011--Mei 2019
}

Fitri Rahmawati ${ }^{1}$ and Nirmala Baini ${ }^{2}$

${ }^{1}$ Universitas Islam Negeri Sunan Kalijaga Yogyakarta

Email: fitri.rahmawatil6@gmail.com

${ }^{2}$ Universitas Islam Negeri Sunan Kalijaga Yogyakarta

Email: nirmalabaini495@gmail.com

\section{INFO ARTIKEL}

Keywords:Indonesia Sharia Stock Index (ISSI), Bank Indonesia Certificates Sharia (SBIS), BI Rate, Exchange Rates (Kurs), FED Rate, and World Gold Price

DOI:

http://dx.doi.org/10.31332/lifalah.v4i2.1473
A B S T R A C T

This study aims to find out empirically the effect of macroeconomics variables on the movements of the Indonesian Islamic Stock Index (ISSI). This research uses quantitative research methods, using multiple linear regression analysis models. Data collection uses secondary data from documentation related data. Data is taken from the monthly closing price of each variable from May 2011 to May 2019. The research test uses the $t$ test and $F$ test and is processed using Eviews8. The results showed that BI Rate and Exchange Rates (Kurs) has a negative and signifcant impact on Indonesia Sharia Stock Index (ISSI). However, the variable Bank Indonesia Certificates Sharia (SBIS), FED Rate, and World Gold Price, they do not have signficant influence on the Indonesia Sharia Stock Index (ISSI). The results showed that Bank Indonesia Certificates Sharia (SBIS), BI Rate, Exchange Rates (Kurs), FED Rate, and World Gold Price had a significant simultaneous effect on the ISSI, and the result of determination coefficient adjusted $R^{2}$ values of $35,2 \%$.

\section{Pendahuluan}

Pasar modal memiliki peranan besar bagi perekonomian suatu negara karena pasar modal menjalankan dua fungsi sekaligus, yaitu fungsi ekonomi dan keuangan. Dengan adanya pasar modal, 
diharapkan aktivitas perekonomian dapat meningkat karena pasar modal merupakan alternatif pendanaan bagi perusahaan, sehingga dapat beroperasi dengan skala yang lebih besar, dan selanjutnya akan meningkatkan pendapatan perusahaan dan kemakmuran masyarakat luas (Manan, 2012: 24).

Di era globalisasi, salah satu tolok ukur model pembangunan ekonomi di suatu negara adalah maju pesatnya pasar modal. Indonesia adalah salah satu dari negara muslim terbesar di dunia, hal tersebut merupakan pasar yang besar untuk mengembangkan industri keuangan syariah. Investasi syariah di pasar modal memiliki peranan untuk mengembangkan pangsa pasar industri keuangan syariah di Indonesia (Suciningtias, 2015).

Dilihat dari kemajuan perkembangan saham syariah di Indonesia, Indeks Saham Syariah Indonesia (ISSI) memiliki perkembangan kinerja yang cukup baik. Berdasarkan informasi terbaru tentang perkembangan Indeks Saham Syariah Indonesia, ISSI mencatatkan pertumbuhan $20 \%$ year to date per 20 September 2016. Hal ini menunjukan bahwa pertumbuhan ISSI tertinggi dibandingkan dengan indeks saham syariah global lainnya. Head of Islamic Capital Market Development Bursa Efek Indonesia Irwan Abdalloh menuturkan dalam lima tahun terakhir, Indeks Saham Syariah Indonesia (ISSI) tumbuh 43\%, sedangkan Indeks Hargsa Saham Gabungan (IHSG) sebesar 41\% (Finansial Bisnis, 02 Oktober 2016). Selain itu, jika dilihat dari awal mula peluncuran Indeks Saham Syariah Indonesia (ISSI) pada tahun 2011, perkembangan ISSI cukup pesat. Berikut merupakan grafik perkembangan pergerakan ISSI pada Mei 2011 - Mei

\section{Pergerakan Indeks Saham Syariah Indonesia (ISSI) Periode Mei 2011 - Mei 2019}

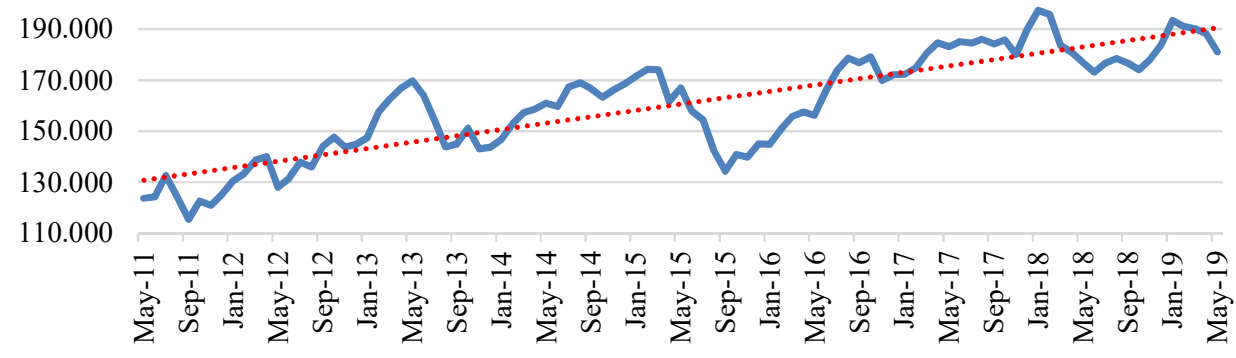

$\longrightarrow$ ISSI $\cdots \cdots$ Linear (ISSI)

Gambar 1 Pergerakan Indeks Saham Syariah Indonesia (ISSI)

Periode Mei 2011-Mei 2019

(Sumber: Bursa Efek Indonesia 2019, data diolah) 
Berdasarkan grafik di atas, dapat dilihat bahwa pergerakan Indeks Saham Syariah Indonesia (ISSI) mengalami fluktuatif, akan tetapi pergerakan tersebut cenderung positif, garis putus-putus tersebut menggambarkan tren dari pergerakan Indeks Saham Syariah Indonesia (ISSI). Dari data di atas, jika dilihat dari awal kemunculan ISSI pada Mei 2011 pergerakan ISSI sebesar 123,812 poin, dan pada Desember 2011 pergerakan ISSI sebesar 125,356 poin (Bursa Efek Indonesia, 2019). Hal ini menunjukkan peningkatan pergerakan ISSI pada saat awal kemunculannya. Meskipun berfluktuasi dan sempat mengalami penurunan, namun menurunnya pergerakan ISSI tidak berlangsung lama sebab pada periode-periode selanjutnya pergerakan
ISSI menunjukkan tren positif. Seperti yang terlihat pada awal tahun 2018, yakni pada Januari 2018 pergerakan Indeks Saham Syariah Indonesia (ISSI) sebesar 197,464 poin yang merupakan puncak pergerakan ISSI selama periode Mei 2011-Mei 2019.

Pada awal tahun 2018 terjadi peningkatan kapitalisasi pasar Indeks Saham Syariah Indonesia (ISSI). Per 29 Januari 2018, kapitalisasi pasar ISSI yang memuat 366 saham mencapai angka $\mathrm{Rp}$ $3.896,0$ Triliun atau $52,4 \%$ dari total kapitalisasi saham-saham yang terdaftar di Bursa Efek Indonesia (Bursa Efek Indonesia, 2019). Berikut merupakan grafik perkembangan kapitalisasi Indeks Saham Syariah Indonesia (ISSI) pada tahun 20112018.

\section{Kapitalisasi Indeks Saham Syariah Indonesia (ISSI) Tahun 2011-2018 (dalam triliun rupiah)}

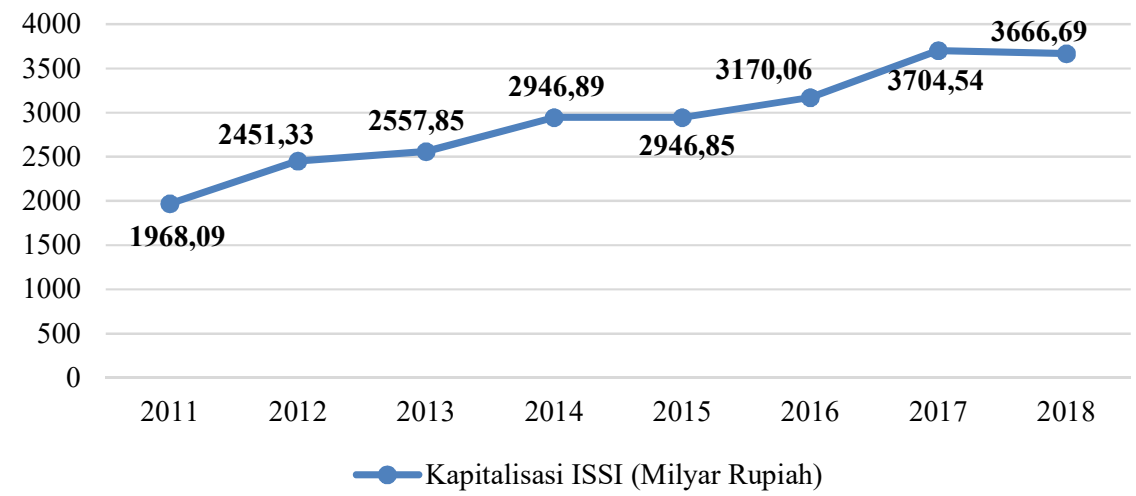

\section{Gambar 2 Grafik Kapitalisasi Indeks Saham Syariah Indonesia (ISSI)} Tahun 2011-2018

(Sumber: Otoritas Jasa Keuangan 2019, data diolah) 


\begin{abstract}
Berdasarkan data di atas, kapitalisasi Indeks Saham Syariah Indonesia (ISSI) dari tahun ke tahun cenderung meningkat. Pertumbuhan kapitalisasi pasar (market capital) sahamsaham syariah yang tergabung dalam konstituen ISSI terhitung sejak tahun 2011 sampai dengan 2018 meningkat dari semula
\end{abstract} Rp. 1.968,09 Triliun menjadi Rp. 3.666,69 Triliun atau naik Rp. 1.698,60 Triliun setara dengan $86,31 \%$ selama 8 tahun (Otoritas Jasa Keuangan, 2018). Hal ini menunjukkan bahwa minat investor terhadap saham-saham syariah semakin hari semakin tinggi dan jumlah investornya semakin banyak. Hal tersebut dibuktikan dengan terus meningkatnya kapitalisasi pasar saham-saham syariah, artinya jumlah modal yang diinvestasikan dalam sahamsaham syariah terus meningkat dari waktu ke waktu.

Pada sisi lain, harus diakui bahwa masih terdapat beberapa masalah mendasar yang menjadi kendala berkembangnya pasar modal yang berprinsip syariah di Indonesia (Sutedi, 2011). Menurut Syahrir (1995) terdapat faktor-faktor penting yang mampu mempengaruhi perkembangan indeks syariah yaitu oleh beberapa variabel makro ekonomi dan moneter seperti Sertifikat Bank Indonesia Syariah (SBIS), inflasi, jumlah uang beredar, nilai tukar dan lain-lain. Sedangkan faktor internal yang mampu mempengaruhi adalah seperti kondisi ekonomi nasional, keamanan, kondisi politik, kebijakan pemerintah dan lain-lain. Sedangkan menurut Blanchard (2006), terdapat faktor yang dapat mempengaruhi pergerakan indeks saham, antara lain perubahan tingkat suku bunga bank sentral, keadaan ekonomi global, tingkat harga energi dunia, kestabilan politik suatu negara dan variabel lainnya.

Perubahan yang terjadi pada faktor makro ekonomi seperti inflasi, suku bunga dan nilai tukar mata uang akan direaksi oleh pasar modal sehingga faktor tersebut berpotensi untuk memengaruhi terbentuknya harga saham (Tandelilin, 2010: 341). Tingkat suku bunga adalah salah satu variabel makro ekonomi yang diperkirakan mempunyai pengaruh terhadap pergerakan indeks harga saham. Berdasarkan data yang diperoleh dari Bank Indonesia, pada tahun 2011-2018 tingkat imbalan Sertifikat Bank Indonesia Syariah (SBIS) mengalami fluktuasi. Berikut merupakan grafik perkembangan Sertifikat Bank Indonesia Syariah. 


\section{Rata-Rata Tingkat Imbalan Sertifikat Bank Indonesia Syariah (SBIS) Tahun 2011-2018}

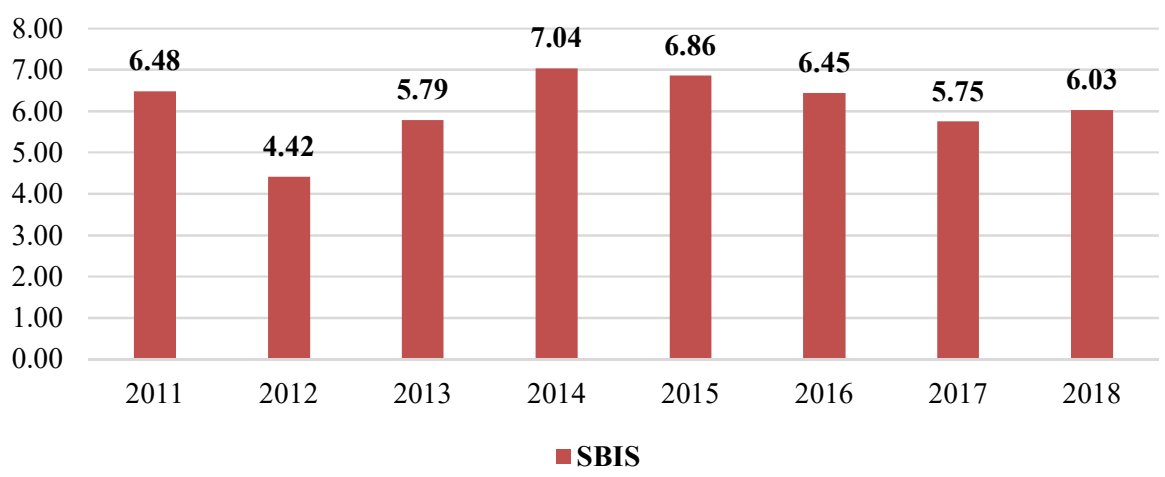

\section{Gambar 3 Rata-Rata Tingkat Imbalan Sertifikat Bank Indonesia Syariah (SBIS) Tahun 2011-2018}

(Sumber: Bank Indonesia 2019, data diolah)

Berdasarkan grafik di atas, dapat diketahui bahwa tingkat imbalan Sertifikat Bank Indonesia Syariah (SBIS) terendah pada tahun 2012 sebesar $4,42 \%$ dan tingkat imbalan SBIS tertinggi pada tahun 2014 sebesar 7,04\%. Sementara kapitalisasi Indeks Saham Syariah Indonesia (ISSI) pada tahun 2012 sebesar Rp. 2.541.33 Triliun dengan rata-rata pergerakan ISSI berada di angka 138,09 poin, dan pada tahun 2014 sebesar Rp. 2.946.89 Triliun dengan rata-rata pergerakan ISSI berada di angka 161,50 poin (Bursa Efek Indonesia, 2019). Oleh sebab itu perlu mengetahui bagaimana pengaruh dari tingkat imbalan Sertifikat Bank Indonesia Syariah (SBIS) terhadap pergerakan indeks saham syariah.

Menurut Triswati (2011), Konsep mengenai BI Rate sebagai policy rate atau suku bunga kebijakan memang lekat dengan tingkat imbalan Sertifikat Bank Indonesia Syariah (SBIS) sebagai instrumen operasinya. BI Rate memegang pernanan penting dalam mempengaruhi aktivitas di pasar modal. Pengaruh tingkat suku bunga berhubungan dengan kinerja perusahaan. Jika tingkat suku bunga naik maka akan meningkatan beban perusahaan yang akan berdampak pada laba perusahaan yang akhirnya akan mempengarui keputusan investor untuk membeli saham perusahaan atau tidak.

Selain BI Rate, di dalam perekonomian domestik maupun global nilai kurs yang merupakan alat pembayaran internasional juga dapat mempengaruhi perekonomian termasuk investasi. Hal ini berkaitan dengan saham yang dimiliki oleh 
perusahaan ekspor maupun impor. Meningkatnya ekspor akan menambah profitabilitas pada perusahaan serta meningkatkan deviden yang diterima oleh investor, tentu saja hal tersebut akan menarik investor untuk berinvestasi. Hal ini terjadi ketika perusahaan ekspor memiliki piutang luar negeri, nilai tukar yang mengalami depresiasi akan mendapat dampak positif yaitu meningkatnya ekspor.

Kondisi perekonomian global diperkirakan mempunyai pengaruh terhadap pasar modal di Indonesia. Pada bulan Juni 2018, Federal Open Market Committee (FOMC) bank sentral Amerika Serikat memutuskan untuk menaikkan kisaran target bunga acuan federal (fed fund rate) menjadi $1,75 \%$ hingga $2 \%$. Kenaikan suku bunga ini direspon oleh negara berkembang termasuk Indonesia. Sebelumnya sudah pernah terjadi perang dagang antara Amerika Serikat dan China dan tahun ini suku bunga The Fed (FED Rate) sudah naik dua kali, namun pasar selalu merespons positif, karena BI selalu ikut dengan menaikan suku bunga acuan untuk jaga kestabilan rupiah (Kontan.co.id, Juni 2018).

Sebagai negara dengan nilai perekonomian tinggi di dunia, tentu resesi di Amerika Serikat akan secara signifikan menghantam perekonomian negara-negara lain, termasuk negara-negara kawasan Asia. Indonesia pun harus menanggung koreksi di pasar saham akibat kekhawatiran para investor. Amerika Serikat adalah negara yang penting bagi Indonesia. Badan Pusat Statistik (BPS) mencatat, ekspor nonmigas Indonesia ke Amerika Serikat sepanjang 2018 mencapai \$17,67 Milyar. Amerika Serikat menduduki peringkat kedua setelah Tiongkok dengan porsi 10,87\% (Beritagar.id, 26 Maret 2019).

Faktor lain dari perekonomian global yang diperkirakan mempunyai pengaruh terhadap pasar modal di Indonesia yaitu harga emas dunia. Pada masa globalisasi saat ini, banyak investor memilih untuk berinvestasi pada sektor pertambangan, khususnya emas. Emas merupakan global currency yang nilainya diakui secara universal. Emas memiliki nilai intrinsik yang tetap dan standar sehingga bisa dibeli dan dicairkan dimana saja. Emas bersifat tidak terpengaruh oleh inflasi (zero inflation) sehingga harga emas selalu mengikuti pergerakan inflasi. Peningkatan harga emas dari tahun ke tahun dan kecilnya tingkat resiko ini diperkirakan dapat mempengaruhi pergerakan indeks harga saham.

\section{Landasan Teori}

Pasar modal adalah salah satu alternatif investasi bagi masyarakat. Melalui pasar modal, investor dapat melakukan investasi di beberapa perusahaan melalui pembelian surat-surat 
berharga yang di tawarkan atau yang diperdagangkan di pasar modal. Dewasa ini, pasar modal memegang peran kunci bagi kemajuan ekonomi suatu negara, keberadaannya bukanlah sekedar memberikan sebuah lahan atau pilihan investasi, namun senantiasa menyediakan pasokan sumber dana yang berkesinambungan (Hermuningsih, 2012). Menurut ketua BAPEPAM, berkembangnya produk pasar modal berbasis syariah merupakan potensi sekaligus tantangan pengembangan pasar modal di Indonesia. Terdapat dua strategi utama yang dicanangkan BAPEPAM untuk mencapai pengembangan pasar modal syariah dan produk pasar modal syariah yaitu mengembangkan kerangka hukum untuk memfasilitasi pengembangan pasar modal berbasis syariah dan mendorong pengembangan produk pasar modal berbasis syariah (Huda, 2007: 58).

\subsection{Indeks Saham Syariah Indonesia (ISSI)}

Tonggak perkembangan pasar modal syariah di Indonesia di awali dengan dikeluarkannya JII (Jakarta Islamic Index) pada tanggal 3 Juli 2000. Kemudian pada tanggal 12 Mei 2011 BEI meluncurkan Indeks Saham Syariah Indonsia (ISSI) (Susyanti, 2016: 215). Tujuan diadakannya Indeks Islam yaitu sebagai tolok ukur untuk mengukur kinerja investasi pada saham yang berbasis syariah dan meningkatkan kepercayaan para investor untuk mengembangkan investasi dalam ekuiti secara syariah, atau untuk memberikan kesempatan kepada investor yang ingin melakukan investasi sesuai dengan prinsipprinsip syariah (Sutedi, 2011: 53).

Menurut Bursa Efek Indonesia (2019), Indeks Saham Syariah Indonesia (ISSI) merupakan indikator dari kinerja pasar saham syariah Indonesia. Konstituen ISSI adalah seluruh saham syariah yang tercatat di Bursa Efek Indonesia (BEI) dan masuk ke dalam Daftar Efek Syariah (DES) yang diterbitkan oleh Otoritas Jasa Keuangan (OJK). Per 18 Januari 2019 daftar saham yang masuk dalam perhitungan Indeks Saham Syariah Indonesia (ISSI) sebanyak 403 saham dari yang sebelumnya berjumlah 212 pada periode 8 Juni 2011. Hal ini menunjukkan konsistensi perkembangan saham syariah, dari awal periode hingga saat ini terdapat 191 saham baru yang masuk ke dalam daftar ISSI.

\subsection{Sertifikat Bank Indonesia Syariah (SBIS)}

Pengertian Sertifikat Bank Indonesia Syariah (SBIS) menurut Bank Indonesia adalah surat berharga berdasarkan prinsip syariah berjangka waktu pendek dalam mata uang rupiah yang 
diterbitkan oleh Bank Indonesia.

Berdasarkan fatwa Dewan Syariah

Nasional-Majelis Ulama Indonesia (DSN-

MUI), SBIS juga dapat diterbitkan dengan menggunakan akad mudharabah, musyarakah, wadiah, qardh, dan wakalah.

\subsection{BI Rate}

BI Rate yaitu merupakan suku bunga kebijakan yang mencerminkan sikap kebijakan moneter yang ditetapkan oleh Bank Indonesia. Sejak 19 Agustus 2016 Bank Indonesia mengimplementasikan suku bunga acuan atau suku bunga kebijakan baru yaitu BI 7-Day (Reverse) Repo Rate menggantikan BI Rate. Instrumen tersebut digunakan sebagai suku bunga kebijakan baru karena dapat secara cepat mempengaruhi pasar uang, perbankan, dan sektor riil.

\subsection{Kurs}

Nilai tukar atau kurs mata uang adalah catatan harga pasar dari mata uang asing dalam harga mata uang domestik, yaitu harga mata uang domestik dalam mata uang asing (Karim, 2008: 157). Terdapat tiga jenis sistem kurs, yaitu sistem kurs mengambang bebas, sistem kurs tetap, dan sistem kurs terkendali (Samuelson, 2009).

\subsection{FED Rate}

FED Rate, atau suku bunga Federal Reserve, adalah tingkat suku bunga yang ditetapkan oleh The FED sebagai patokan bagi suku bunga pinjaman yang digunakan antar lembaga penyimpanan keuangan di seluruh Amerika Serikat dalam waktu semalam. The Fed merupakan badan keuangan yang bertanggung jawab dalam mengatur perbankan dan mengatur jumlah uang beredar dalam perekonomian adalah Federal Reserve (Bank Sentral Amerika Serikat) yang sering disingkat dengan The Fed (Mankiw, 2002: 176).

\subsection{Emas Dunia}

Emas merupakan salah satu komoditas dunia yang pernah digunakan sebagai alat tukar atau pembayaran, emas merupakan global currency yang nilainya diakui secara universal. Selain itu harga emas tidak terpengaruh oleh adanya inflasi atau dengan kata lain dapat dikatakan zero inflation maka dari itu harga emas selalu mengikuti pergerakan inflasi.

\section{Penelitian Terdahulu}

Penelitian yang dilakukan oleh Suciningtias (2015), Saputra (2017) menghasilkan kesimpulan bahwa Sertifikat Bank Indonesia Syariah (SBIS) tidak memiliki pengaruh terhadap Indeks Saham Syariah Indonesia (ISSI). Berbeda dengan penelitian yang dilakukan oleh Ardana (2016), Wahyuningrum (2016) bahwa 
Sertifikat Bank Indonesia Syariah (SBIS) memiliki pengaruh positif dan signifikan terhadap Indeks Saham Syariah Indonesia (ISSI). Sedangkan penelitian yang dilakukan oleh Arif (2018), Sudjono (2002) menghasilkan kesimpulan bahwa Sertifikat Bank Indonesia Syariah (SBIS) memiliki korelasi yang negatif.

$$
\text { Penelitian mengenai }
$$
pengaruh BI Rate terhadap indeks saham syariah yang dilakukan oleh Muttaqin (2017), Pasaribu (2013), Wahid (2018), Putri (2018) memiliki pengaruh positif. Kemudian penelitian yang dilakukan oleh Saputra (2017), Insiyah (2017) BI Rate tidak memiliki pengaruh terhadap indeks saham syariah. Sedangkan penelitian yang dilakukan oleh Widyasa (2018), Ardana (2016), Mawarni (2018), menghasilkan kesimpulan bahwa BI Rate berpengaruh negatif terhadap Indeks Saham Syariah Indonesia (ISSI).

Penelitian yang dilakukan oleh Suciningtias (2015), Rachmawati (2015), Widyasa (2018), Mawarni (2018), Wahyuningrum (2016), Karlina (2017) menghasilkan kesimpulan bahwa kurs berpengaruh negatif terhadap Indeks Saham Syariah Indonesia (ISSI). Sedangkan penelitian yang dilakukan oleh
Saputra (2017) menghasilkan kesimpulan bahwa kurs berpengaruh positif terhadap Indeks Saham Syariah Indonesia (ISSI).

Penelitian yang dilakukan oleh Mawarni (2018), Wicaksono (2017), Wijayaningsih (2016) menghasilkan kesimpulan bahwa FED Rate tidak memiliki pengaruh terhadap Indeks Saham. Kemudian penelitian yang dilakukan oleh Miyanti (2018) menghasilkan kesimpuln bahwa FED Rate memiliki pengaruh positif terhadap indeks saham. Semetara penelitian yang dilakukan oleh Misgiyanti (2009) menghasilkan kesimpulan bahwa FED Rate memiliki pengaruh yang negatif terhadap indeks saham.

Penelitian mengenai harga emas dunia terhadap indeks saham yang dilakukan oleh Wahid (2018), Insiyah (2017), Sartika (2017), Arintika (2015) menghasilkan kesimpulan bahwa harga emas dunia tidak berpengaruh terhadap indeks saham. Sedangkan penelitian yang dilakukan oleh Moore (1990) menemukan bahwa harga emas memiliki korelasi yang negatif terhadap harga saham. Sementara penelitian yang dilakukan oleh Gumilang (2014) menghasilkan kesimpulan bahwa harga emas dunia berkorelasi positif terhadap indeks saham 


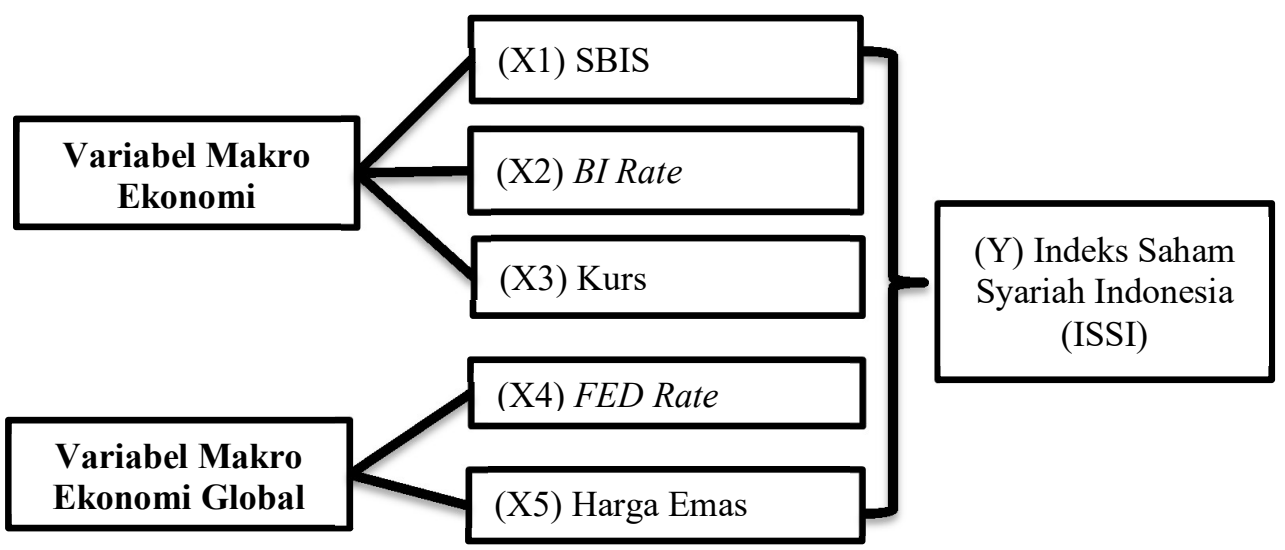

\section{Gambar 4 Kerangka Pemikiran Penelitian}

Hipotesis

1. Ha1: Sertifikat Bank Indonesia Syariah (SBIS) berpengaruh terhadap Indeks Saham Syariah Indonesia (ISSI)

2. Ha2: BI Rate berpengaruh terhadap Indeks Saham Syariah Indonesia (ISSI)

3. Ha3: Kurs berpengaruh terhadap Indeks Saham Syariah Indoneisa (ISSI)

4. Ha4: FED Rate berpengaruh terhadap Indeks Saham Syariah Indoneisa (ISSI)

5. Ha5: Harga Emas Dunia berpengaruh terhadap Indeks Saham Syariah Indoneisa (ISSI).

\section{Metodologi Penelitian \\ 4.1 Jenis Penelitian}

Jenis penelitian ini termasuk dalam penelitian kuantitaif, dan jenis data dalam penelitian ini adalah sekunder. Dalam penelitian ini variabel terikat (dependen) yaitu Indeks Saham Syariah Indonesia
(ISSI), sedangkan variabel bebas (independen) daam penelitian ini yaitu Sertifikat Bank Indonesia Syariah (SBIS), BI Rate, Kurs, FED Rate, dan Harga Emas Dunia.

\subsection{Sumber Data}

Sumber data dalam penelitian ini diperoleh dari website yang berkaitan dengan variabel penelitian antara lain https://www.duniainvestasi.com untuk memperoleh data Indeks Saham Syariah Indonesia (ISSI), https://www.bi.go.id untuk memperoleh data Sertifikat Bank Indonesia Syariah

(SBIS), https://www.pusatdata.kontan.co.id untuk memperoleh data BI Rate, https://www.kemendag.go.id untuk memperoleh data kurs, https://fred.stlouisfed.org untuk memperoleh data FED Rate, https://id.investing.com untuk memperoleh data harga emas dunia. 


\subsection{Populasi dan Sampel}

Populasi yang digunakan dalam penelitian ini adalah data pergerakan Indeks Saham Syariah Indonesia (ISSI), Sertifikat Bank Indonesia Syariah (SBIS), BI Rate, Kurs, FED Rate, dan Harga Emas Dunia selama periode Mei 2011 - Mei 2019. Dalam penelitian ini menggunakan teknik purposive sampling. Data yang digunakan sebagai sampel yaitu berupa data harga penutupan (closing price) Indeks Saham Syariah Indonesia (ISSI), data bulanan tingkat imbalan Sertifikat Bank Indonesia Syariah (SBIS), data bulanan $B I$ Rate, data bulanan nilai tukar (kurs) IDR/USD, data bulanan FED Rate, dan data bulanan harga emas berjangka.

\subsection{Teknik Analisis Data}

Metode analisis yang digunakan dalam penelitian ini adalah metode analisis regresi linear berganda yang dibantu dengan software Eviews8. Model regresi linear berganda yang digunakan adalah sebagai berikut:

$Y=\beta_{0}+\beta_{1} X_{1}+\beta_{2} X_{2}+\beta_{3} X_{3}+\beta_{4} X_{4}+\beta_{5} X_{5}+\varepsilon$
$\mathrm{Y}=$ Indeks Saham Syariah Indonesia (ISSI)

$\beta_{0}=$ Konstanta

$\beta_{1-5}=$ Koefisien Regresi

$\mathrm{X}_{1}=$ Sertifikat Bank Indonesia Syariah (SBIS)

$\mathrm{X}_{2}=$ BI Rate

$\mathrm{X}_{3}=$ Kurs

$\mathrm{X}_{4}=$ FED Rate

$\mathrm{X}_{5}=$ Harga Emas Dunia

\section{Hasil Penelitian}

Berdasarkan hasil penelitian maka diperoleh hasil uji asumsi klasik sebagai berikut ini:

\subsection{Uji Autokorelasi}

Uji autokorelasi bertujuan menguji apakah model linier ada korelasi antara kesalahan penggaggu pada periode t-1 (sebelumnya). Untuk menguji ada tidaknya autokorelasi dapat dilakukan dengan beberapa pengujian yaitu: Durbin-Watson, Breusch-Godfrey, dan Run Test. Dalam penelitian ini penulis menggunakan pengujian Breusch-Godfrey, model ini dikenal dalam uji Lagrange Multiplier (LM). Syarat uji LM adalah jika probabilitas Ch-Square $<\alpha=1 \%, 5 \%$, dan $10 \%$ maka terdapat masalah autokorelasi. Berikut merupakan hasil dari pengujian autokorelas dalam penelitian ini:

Keterangan: 


\section{Tabel 1}

\section{Hasil Uji Autokorelasi}

Breusch-Godfrey Serial Correlation LM Test:

\begin{tabular}{llll}
\hline \hline F-statistic & 112.4044 & Prob. F(2,89) & 0.0000 \\
Obs*R-squared & 69.48962 & Prob. Chi-Square(2) & 0.0000 \\
\hline \hline
\end{tabular}

(sumber: data diolah, 2019

Berdasarkan hasil nilai Prob. Chi- Difference. Jadi, merumuskan persamaan Square $=0,0000<$ nilai kritis $1 \%, 5 \%$ dan regresi pada $Y$ dan $X_{1}, X_{2}, \ldots X_{n}$, $10 \%$ sehingga terdapat masalah menggunakan persamaan regresi autokorelasi.

Pada data time series (runtut waktu) sering terjadi masalah autokorelasi. Hal ini disebabkan karena adanya gangguan. Cara untuk mengatasi gangguan autokorelasi dalam penelitian ini menggunakan berdasarkandifference, yaitu $Y_{t}^{\prime}=Y_{t}-Y_{t-1}$ dan $X_{t 1}^{\prime}=X_{t}-X_{t-1,1}, X_{t 2}^{\prime}=X_{t}-X_{t 1,2, \cdots}$ dan seterusnya.

Hasil dari uji Lagrange Multiplier (LM) setelah menggunakan data hasil transformasi first difference adalah sebagai transformasi dalam bentuk First berikut:

Tabel 2

Hasil Uji Autokorelasi (first difference)

Breusch-Godfrey Serial Correlation LM Test:

\begin{tabular}{llll}
\hline \hline F-statistic & 0.116325 & Prob. F(2,88) & 0.8903 \\
Obs*R-squared & 0.253132 & Prob. Chi-Square(2) & 0.8811 \\
\hline \hline
\end{tabular}

(Sumber: data diolah, 2019)

Berdasarkan hasil nilai Prob. Chi-

Square $=0,8811>$ nilai kritis $1 \%, 5 \%$, dan

$10 \%$. sehingga dapat dikatakan model tersebut tidak terdapat masalah autokorelasi dan regresi layak digunakan.

\section{$5.2 \quad$ Uji Normalitas}

Uji normalitas bertujuan untuk menguji apakah dalam model regresi, variabel pengganggu atau residua memiliki distribusi normal. Untuk mengetahuinya dengan menggunakan nilai statistic JarqueBerra. Berikut merupakan hasil dari uji normalitas dalam penelitian ini. 


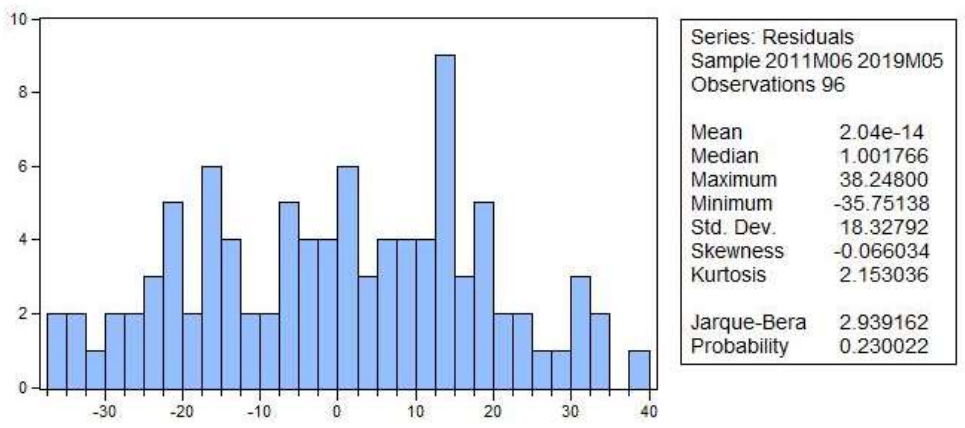

Gambar 5 Uji Normalitas

(Sumber: data diolah, 2019)

Berdasarkan nilai probability dari homoskedastisitas atau tidak terdapat Jarque-Berra adalah $0,230022>\alpha=5 \% \quad$ heteroskedastisitas. Penentuan masalah atau $1 \%$. sehingga residual berdistribusi heteroskedastisitas dapat dilakukan secara normal.

\subsection{Uji Heteroskedastisitas} statistik dengan beberapa metode. Dalam penelitian ini, peneliti menggunakan

Uji ini bertujuan untuk menguji apakah dalam model regresi terjadi ketidaksamaan varian dari residual satu pengamatan ke pengamatan lain. Jika variannya sama maka disebut metode White, metode ini didasarkan pada jumlah sampel (n) dikalikan dengan $\mathrm{R}^{2}$ yang mengikuti distribusi Chi-Square. Hipotesis Berikut merupakan hasil uji heteroskedastisitas dalam penelitian ini:

Tabel 3

Hasil Uji Heteroskedastisitas

Heteroskedasticity Test: White

\begin{tabular}{llll}
\hline \hline F-statistic & 0.407881 & Prob. F(20,75) & 0.9867 \\
Obs*R-squared & 9.417427 & Prob. Chi-Square(20) & 0.9775 \\
Scaled explained SS & 12.11327 & Prob. Chi-Square(20) & 0.9121 \\
\hline \hline
\end{tabular}

(Sumber: data diolah, 2019)

Berdasarkan hasil uji white nilai

Prob. Chi-Square $(20)=0,99775>\alpha=1 \%$, $5 \%$, atau $10 \%$ sehingga tidak terdapat masalah heteroskedastisitas.

\section{$5.4 \quad$ Uji Multikolinearitas}

Uji multikolinearitas bertujuan untuk menguji apakah model regresi memiliki korelasi antara variabel bebas (independen) atau tidak. Berikut 
merupakan hasil dari uji multikolinaritas

dalam penelitian ini:

Tabel 4

Hasil Uji Multikolinearitas

\begin{tabular}{|c|c|c|c|}
\hline Variable & $\begin{array}{l}\text { Coefficient } \\
\text { Variance }\end{array}$ & $\begin{array}{c}\text { Uncentered } \\
\text { VIF }\end{array}$ & $\begin{array}{c}\text { Centered } \\
\text { VIF }\end{array}$ \\
\hline D(SBIS) & 5.460507 & 1.455150 & 1.452511 \\
\hline D(BI_RATE) & 7.323329 & 1.391647 & 1.389577 \\
\hline D(LN_KURS) & 497.6736 & 1.207728 & 1.141602 \\
\hline D(FED_RATE) & 85.60063 & 1.249277 & 1.021631 \\
\hline D(LN_EMAS) & 127.2022 & 1.113773 & 1.112089 \\
\hline $\mathrm{C}$ & 0.284308 & 1.317226 & NA \\
\hline
\end{tabular}

(Sumber: data diolah, 2019)

Syarat terjadinya multikolinear

Untuk mengetahui pengaruh pada model adalah nilai Variance Inflation variabel Sertifikat Bank Indonesia Syariah Factors (VIF) $>10$. Berdasarkan hasil (SBIS), BI Rate, kurs, FED Rate, dan harga Centered VIF masing-masing variabel $<10$. emas dunia terhadap Indeks Saham Syariah Sehingga dapat disimpulkan tidak terdapat Indonesia (ISSI) digunakan teknik analisis masalah multikolinear.

\subsection{Pengujian Analisis Regresi pengolahan data dengan menggunakan Linear Berganda software Eviews8 diperoleh hasil sebagai berikut:}

Tabel 5

Hasil Uji Regresi Linear Berganda

\begin{tabular}{ccccc}
\hline \hline Variable & Coefficient & Std. Error & t-Statistic & Prob. \\
\hline \hline C & 1.133430 & 0.533205 & 2.125691 & 0.0363 \\
D(SBIS) & 3.944073 & 2.336773 & 1.687829 & 0.0949 \\
D(BI_RATE) & -7.320023 & 2.706165 & -2.704944 & 0.0082 \\
D(LN_KURS) & -128.3061 & 22.30860 & -5.751420 & 0.0000 \\
D(FED_RATE) & 6.020515 & 9.252061 & 0.650722 & 0.5169 \\
D(LN_EMAS) & 6.337979 & 11.27839 & 0.561958 & 0.5755 \\
\hline \hline
\end{tabular}

(Sumber: data diolah, 2019)

Dari tabel di atas, dapat dibentuk persamaan regresi berganda sebagai berikut:

$$
Y_{t}^{\prime}=\beta_{1} X_{1}^{\prime}+\beta_{2} X_{2}^{\prime}+\beta_{3} X_{3}^{\prime}+\beta_{4} X_{4}^{\prime}+\beta_{5} X_{5}^{\prime}
$$

$$
\mathrm{Y}_{\mathrm{t}}^{\prime}=3,94 \mathrm{X}_{1}^{\prime}-7,32 \mathrm{X}_{2}{ }^{\prime}-128,31 \mathrm{X}_{3}{ }^{\prime}+6,02 \mathrm{X}_{4}{ }^{\prime}+6,34 \mathrm{X}
$$

Keterangan:

$\mathrm{Y}_{\mathrm{t}}{ }^{\prime} \quad=$ Indeks Saham Syariah Indonesia (ISSI) 


$$
\begin{array}{ll}
\mathrm{X}_{1}{ }^{`} & =\text { Difference_SBIS } \\
\mathrm{X}_{2}{ }^{{ }} & =\text {Difference_BI Rate } \\
\mathrm{X}_{3}{ }^{{ }^{\prime}} & =\text { Difference_Kurs } \\
\mathrm{X}_{4}{ }^{{ }^{\prime}} & =\text { Difference_FED Rate } \\
\mathrm{X}_{5}{ }^{{ }^{\prime}} & =\text { Difference_Harga Emas }
\end{array}
$$

Dunia

$$
\varepsilon=\text { Error of Estimation }
$$

Berdasarkan persamaan regresi di atas maka nilai koefisien dapat diintepretasikan sebagai berikut:

Pada nilai koefisien regresi Sertifikat Bank Indonesia Syariah (SBIS) sebesar 3,94 berarti apabila tingkat imbalan SBIS meningkat $1 \%$ maka akan menaikan nilai Indeks Saham Syariah Indonesia (ISSI) sebesar 3,94 poin dengan asumsi variabel lain dianggap konstan.

Nilai koefisien regresi BI Rate sebesar -7,32 berarti apabila terjadi peningkatan BI Rate sebesar 1\% maka akan menurunkan nilai Indeks Saham Syariah Indonesia (ISSI) sebesar 7,32 poin dengan asumsi variabel lain dianggap konstan.

Nilai koefisien regresi Kurs sebesar $-128,31$ berarti apabila nilai kurs mengalami kenaikan sebesar 1\% maka akan menurunkan nilai Indeks Saham Syariah Indonesia (ISSI) sebesar 128,31 poin dengan asumsi variabel lain dianggap konstan.

Nilai koefisien regresi FED Rate sebesar 6,02 hal ini menunjukan apabila terjadi peningkatan FED Rate maka akan menaikan nilai Indeks Saham Syariah
Indonesia (ISSI) sebesar 6,02 poin dengan asumsi variabel lain dianggap konstan.

Kemudian nilai regresi harga emas dunia sebesar 6,34 berarti apabila terjadi peningkatan harga emas dunia sebesar $1 \%$ maka akan menaikan nilai Indeks Saham Syariah Indonesia (ISSI) sebesar 6,34 poin dengan asumsi variabel lain dianggap konstan.

\subsection{Uji F (F-test)}

Uji F (F-test) adalah uji serempak yang digunakan untuk mengetahui pengaruh variabel independen secara simultan terhadap variabel dependen. Berikut merupakan hasil dari pengujian uji $\mathrm{F}(F$-test $)$ :

\section{Tabel 6} Hasil Uji Statistik F

\begin{tabular}{cc}
\hline Indikator & Nilai \\
\hline Prob (F-statistic) & 0,000000 \\
\hline (Sumber: data diolah, 2019)
\end{tabular}

Tabel di atas menunjukan bahwa probabilitas atau signifikansi dari $F$ statistic sebesar $0,000000<0,05$ hal ini menunjukan bahwa variabel Sertifikat Bank Indonesia Syariah (SBIS), BI Rate, kurs, FED Rate, dan harga emas dunia secara bersama-sama berpengaruh signifikan terhadap variabel Indeks Saham Syariah Indonesia (ISSI).

\section{$5.7 \quad R^{2}$ (Koefisien Determinasi)}


Nilai R ${ }^{2}$ (Koefisien Determinasi) ini digunakan untuk mengetahui seberapa besar kemampuan variabel independen menjelaskan variabel dependen. Berikut merupakan hasil dari pengujian uji determinasi $\left(\mathrm{R}^{2}\right)$ :

Tabel 7

Hasil Uji Koefisien Determinasi $\left(\mathbf{R}^{2}\right)$

\begin{tabular}{cc}
\hline Indikator & Nilai \\
\hline Adjusted R-Squared & 0,316055 \\
\hline
\end{tabular}

(Sumber: data diolah, 2019)

Dari data di atas, menunjukan bahwa nilai Adjusted R-Squared sebesar 0,316055. hal ini menunjukan bahwa $31,6 \%$ variasi variabel Indeks Saham Syariah Indonesia (ISSI) dapat dijelaskan oleh variasi variabel Sertifikat Bank Indonesia Syariah (SBIS), BI Rate, kurs, FED Rate, dan harga emas dunia. Sedangkan sisanya sebesar $68,4 \%$ dijelaskan oleh variabel lain di luar model regresi.

\subsection{Pengujian Hipotesis dengan Uji t $(t$-test $)$}

Uji t digunakan untuk membuktikan pengaruh variabel independen terhadap variabel dependen secara individual dengan asumsi bahwa variabel lain dianggap tetap atau konstan. Pengambilan kesimpulannya ialah dengan membandingkan antara nilai probabilitas dengan nilai $\alpha(0,05)$. Berikut merupakan hasil dari pengujian hipotesis dengan uji $\mathrm{t}(t$-test):

\section{a. Pengaruh Sertifikat Bank Indonesia Syariah (SBIS) terhadap Indeks Saham Syariah Indonesia (ISSI)}

Berdasarkan hasil pengujian secara parsial atau individual, diperoleh nilai probabilitas dari variabel Sertifikat Bank Indonesia Syariah (SBIS) sebesar 0,0949> 0,05 , sehingga $\mathrm{H}_{0}$ diterima. Artinya bahwa variabel Sertifikat Bank Indonesia Syariah (SBIS) tidak memiliki pengaruh terhadap Indeks Saham Syariah Indonesia (ISSI).

\section{b. Pengaruh BI Rate terhadap Indeks Saham Syariah Indonesia (ISSI)}

Berdasarkan hasil pengujian secara parsial atau individual, diperoleh nilai probabilitas dari variabel BI Rate sebesar $0,0082<0,05$, sehingga $\mathrm{H}_{0}$ ditolak. Sehingga diperoleh hasil bahwa variabel $B I$ Rate secara parsial atau individu berpengaruh negatif dan signifikan terhadap Indeks Saham Syariah Indonesia (ISSI).

\section{c. Pengaruh Kurs terhadap Indeks Saham Syariah Indonesia (ISSI)}

Berdasarkan hasil pengujian secara parsial atau individual, diperoleh nilai 
probabilitas dari variabel kurs sebesar $0,0000<0,05$, sehingga $\mathrm{H}_{0}$ ditolak. Sehingga diperoleh hasil bahwa variabel kurs memiliki pengaruh negatif terhadap Indeks Saham Syariah Indonesia (ISSI).

\section{d. Pengaruh FED Rate terhadap Indeks Saham Syariah Indonesia (ISSI)}

Berdasarkan hasil pengujian secara parsial atau individual, diperoleh nilai probabilitas dari variabel Kurs sebesar $0,5169>0,05$, sehingga $\mathrm{H}_{0}$ diterima. Artinya bahwa variabel FED Rate tidak memiliki pengaruh terhadap Indeks Saham Syariah Indonesia (ISSI).

\section{e. Pengaruh Harga Emas Dunia terhadap Indeks Saham Syariah Indonesia (ISSI)}

Berdasarkan hasil pengujian secara parsial atau individual, diperoleh nilai probabilitas dari variabel harga emas dunia sebesar $0,5755>0,05$, sehingga $\mathrm{H}_{0}$ diterima. Artinya bahwa variabel harga emas dunia tidak memiliki pengaruh terhadap Indeks Saham Syariah Indonesia (ISSI).

\section{Pembahasan}

Perubahan atau perkembangan yang terjadi pada berbagai variabel ekonomi suau negara akan memberikan pengaruh kepada pasar modal, apabila suatu indikator ekonomi makro jelek maka akan berdampak buruk bagi perkembangan pasar modal. Tetapi apabila suatu indikator ekonomi baik maka akan memberi pengaruh yang baik pula terhadap kondisi pasar modal. Dalam kondisi perekonomian yang wajar secara teoritis indeks harga saham selalu berada di atas harga dasarnya. Tetapi dapat pula terjadi dalam suatu perekonomian yang mengalami depresi harga saham berada di bawah harga dasarnya. Perubahan-perubahan angka indeks tersebut dipengaruhi oleh banyak faktor, terutama kondisi perekonomian di negara tersebut maupun global yang mempengaruhi perilaku investor di bursa (Sunariyah, 2003).

\subsection{Pengaruh Sertifikat Bank Indonesia Syariah (SBIS) terhadap Indeks} Saham Syariah Indonesia (ISSI)

Hasil pengujian regresi menghasilkan bahwa Sertifikat Bank Indonesia Syariah (SBIS) tidak memiliki pengaruh terhadap Indeks Saham Syariah Indonesia (ISSI). Hasil penelitian ini juga didukung oleh penelitian yang dilakukan oleh Suciningtias (2015), Saputra (2017). Hasil penelitian menunjukan arah positif, hal ini dikarenakan ketika tingkat imbalan Sertifikat Bank Indonesia Syariah (SBIS) tinggi berakibat pada meningkatnya investasi, hal tersebut terjadi karena 
investor di pasar modal tidak melakukan aksi pengalihan investasi ke dalam deposito ataupun tabungan di perbankan saat tingkat SBSIS tinggi (Suciningtias, 2015).

Tidak adanya pengaruh yang signifikan dari Sertifikat Bank Indonesia Syariah (SBIS) terhadap Indeks Saham Syariah Indonesia (ISSI) diakibatkan oleh tingkat imbalan SBIS yang fluktuatif di tahun 2011-2019. Selama periode penelitian pada Mei 2011 - Mei 2019 ratarata tingkat imbalan SBIS hanya berada di angka $6,11 \%$, angka tersebut masih tergolong sangat kecil sehingga tidak terlalu berpengaruh terhadap investasi di pasar modal.

\subsection{Pengaruh BI Rate terhadap Indeks Saham Syariah Indonesia (ISSI)}

Hasil pengujian regresi menghasilkan bahwa BI Rate berpengaruh negatif dan signifikan terhadap Indeks Saham Syariah Indonesia (ISSI). Hasil penelitian ini sejalan dengan penelitian yang dilakukan oleh Widyasa (2018), Ardana (2016), Mawarni (2018). Pengaruh negatif dari BI Rate sesuai dengan teori yang dikemukakan oleh Tandelilin (2010) bahwa tingkat suku bunga yang terlalu tinggi akan mempengaruhi nilai sekarang aliran kas perusahaan sehingga kesempatan investasi yang ada tidak akan menarik lagi. Selain itu, pada perusahaan yang struktur modalnya banyak menggunakan pinjaman yang berbasis bunga, apabila terjadi kenaikan pada suku bunga pinjaman akan menyebabkan beban bunga kredit meningkat dan akan menurunkan laba bersih. Oleh sebab itu kenaikan suku bunga pinjaman yang tinggi akan berdampak pada harga saham yang lemah, sehingga akan mempengaruhi investasi di pasar modal.

\subsection{Pengaruh Kurs terhadap Indeks Saham Syariah Indonesia (ISSI)}

Hasil pengujian regresi menghasilkan bahwa kurs berpengaruh negatif dan signifikan terhadap Indeks Saham Syariah Indonesia (ISSI). Hasil penelitian ini sejalan dengan penelitian yang dilakukan oleh Suciningtias (2015), Rachmawati (2015), Widyasa (2018), Mawarni (2018), Wahyuningrum (2016), Karlina (2017). Pengaruh yang signifikan dari kurs terhadap Indeks Saham Syariah Indonesia (ISSI) menunjukan bahwa perubahan nilai kurs akan berdampak pada pergerakan Indeks Saham Syariah Indonesia (ISSI). Pengaruh negatif dari kurs terhadap pergerakan indeks saham diakibatkan oleh adanya hubungan perekonomian global. Perubahan kurs mempengaruhi pembentukan harga barang atau jasa ekspor-impor sehingga hal tersebut akan berpengaruh pada profitabilitas perusahaan (Rachmawati, 2015). Ketika profitabilitas perusahaan menurun, banyak investor memilih menjual 
sahamnya dan memilih investasi pada pasar valuta asing. Hal tersebut dapat berakibat pada permintaan saham dan pergerakan indeks saham.

\subsection{Pengaruh FED Rate terhadap Indeks Saham Syariah Indonesia (ISSI)}

Hasil pengujian regresi

menghasilkan bahwa FED Rate tidak berpengaruh terhadap Indeks Saham Syariah Indonesia (ISSI). Hasil penelitian ini didukung oleh penelitian yang dilakukan oleh Mawarni (2018), Wicaksono (2017), Wijayaningsih (2016). Hasil dari penelitian menunjukan arah yang positif. Pengaruh positif antara suku bunga The Fed terhadap harga saham terjadi karena kenaikan suku bunga The Fed dinilai tidak terlalu signifikan oleh investor jika dibandingkan dengan peluang investasi di pasar saham Indonesia yang dinilai masih sangat menjanjikan yang ditunjang juga dengan pertumbuhan perekonomian Indonesia yang positif (Miyanti, 2018).

Tidak adanya pengaruh yang signifikan antara FED Rate dengan Indeks Saham Syariah Indonesia (ISSI) menurut Wijayaningsih (2016) dikarenakan adanya keragaman informasi yang menyebabkan perbedaan pengambilan keputusan yang dilakukan oleh investor. Keragaman informasi ini terjadi karena investor tidak hanya melihat perubahan FED Rate saja, namun juga melihat selisih BI Rate dengan FED Rate sesuai teori paritas suku bunga.

6.5 Pengaruh Harga Emas Dunia terhadap Indeks Saham Syariah Indonesia (ISSI)

Hasil pengujian regresi menghasilkan bahwa harga emas dunia tidak berpengaruh terhadap Indeks Saham Syariah Indonesia (ISSI). Hasil penelitian ini didukung oleh penelitian yang dilakukan oleh Wahid (2018), Insiyah (2017), Sartika (2017), Arintika (2015). Harga emas tidak memiliki pengaruh yang signifikan terhadap Indeks Saham Syariah Indonesia (ISSI) dikarenakan kebanyakan investor membeli emas bukan bertujuan untuk berinvestasi (Insiyah, 2017). Hasil dari penelitian menunjukan arah yang positif dikarenakan penilaian investor terhadap harga emas, apabila harga emas naik maka akan meningkatkan harga saham pada sektor pertambangan yang nantinya akan berdampak pada laba perusahaan yang meningkat sehingga akan menarik investor untuk berinvestasi (Gumilang, 2014).

\section{KESIMPULAN}

Berdasarkan hasil penelitian yang telah dilakukan maka pada penelitian ini dapat ditarik kesimpulan sebagai berikut:

a. Variabel BI Rate dan Kurs mempunyai pengaruh negatif dan signifikan terhadap Indeks Saham Syariah 
Indonesia (ISSI) selama periode Mei 2011 - Mei 2019. Apabila BI Rate dan kurs mengalami kenaikan maka akan menurunkan Indeks Saham Syariah Indonesia (ISSI)

b. Variabel Sertifikat Bank Indonesia Syariah (SBIS), FED Rate, dan Harga Emas Dunia tidak berpengaruh terhadap Indeks Saham Syariah Indonesia (ISSI) selama periode Mei 2011 - Mei 2019.

c. Nilai Adjusted R-Squared sebesar 0,316055. Hal ini menunjukkan bahwa $31,6 \%$ variasi variabel Indeks Saham Syariah Indonesia (ISSI) dapat dijelaskan oleh variasi variabel Sertifikat Bank Indonesia Syariah (SBIS), BI Rate, kurs, FED Rate, dan harga emas dunia. Sedangkan sisanya sebesar $68,4 \%$ dijelaskan oleh variabel lain di luar model regresi.

\section{SARAN}

1. Untuk peneliti selanjutnya dapat menambahkan variabel yang lebih kompleks dan dapat menggunakan alat analisis atau metode yang berbeda, sehingga kedepannya diharapkan dapat menghasilkan penelitian yang lebih baik.

2. Untuk investor diharapkan melakukan pertimbangan terlebih dahulu sebelum

berinvestasi dengan cara mencari
informasi dan melihat
perekondisi
domestik.

\section{Daftar Pustaka}

Ardana, Yudhistira. April 2016. Pengaruh Variabel Makro Ekonomi Terhadap Indeks Saham Syariah di Indonesia: Model ECM, Esensi Jurnal Bisnis dan Manajemen, Vol. 6, No. 1

Arif, Mahdalena.2018. Pengaruh Inflasi, Kurs, dan Tingkat Imbalan Sertifikat Bank Indonesia Syariah (SBIS) Terhadap Harga Saham PT Bank Negara Indonesia (Tbk) di Bursa Efek Indonesia Periode 2010-2017, Skripsi: Fakultas Ekonomi dan Bisnis Islam, Universitas Islam Negeri Sumatera Utara Medan

Arintika, Rista Yuliani, Deannes Isyunuwardhana. April 2015. Pengaruh Inflasi, Suku Bunga SBI, Kurs Valuta Asing, Indeks Harga Konsumen dan Harga Emas Dunia Terhadap Indeks Saham Syariah Indonesia, EProceeding of Management, Vol. 2, No. 1

Badan Pusat Statistik, diakses pada tanggal 28 Maret 2019 pukul 20:32 WIB

(https://www.bps.go.id/subject/3/inflasi.html\#s ubjekViewTab1)

Beritagar.id, diakses pada tanggal 27 Maret 2019 pukul 19:07 WIB (https://beritagar.id/artikel/berita/ekonomiamerika-serikat-di-ambang-resesi-bi-waspada)

Blanchard, Olivier. 2006. European unemployment: the evolution of facts and ideas. Journals Social Sciences Economic Policy. Oxford Universiy Press, Volume 21 Issue $45 \mathrm{Pp}$ 6-59.

Bursa Efek Indonesia, diakses pada tanggal 23 Maret 2019 pukul 10:33 WIB. (https://www.idx.co.id/idx-syariah/indeks$\underline{\text { saham-syariah/) }}$

Finansial Bisnis, diakses pada tanggal 23 Maret 2019 pukul 10:00 WIB 
(https://finansial.bisnis.com/read/20161002/9/ 588755/indeks-saham-syariah-indonesiatumbuh-tertinggi-di-dunia)

Gom, Hotneri G. 2014. Analisis Pengaruh The Fed Rate, Indeks Dow Jones dan Indeks Nikkei 225 terhadap Indeks Harga Saham Gabungan (IHSG) di Bursa Efek Indonesia (BEI) periode 2008-2013. Jurnal Ekonomi dan Keuangan, Vol. 1 No. 8.

Gumilang, Reshinta Candra, dkk. September 2014. Pengaruh Variabel Makro Ekonomi, Harga Emas, dan Harga Minyak Dunia Terhadap Indeks Harga Saham Gabungan, Jurnal Administrasi Bisnis (JAB), Vol. 14, No. 2

Hermuningsih, Sri. 2012. Pengantar Pasar Modal Indonesia. Yogyakarta: UPP STIM YKPN

Huda, Nurul. 2007. Investasi Pada Pasar Modal Syariah, Jakarta: Prenada Media

Insiyah, Jauhar. 2017. Pengaruh Suku Bunga (BI Rate), Harga Emas Dunia, Tingkat Inflasi, Jumlah Uang Beredar dan Harga Minyak Dunia Terhadap Indeks Harga Saham Jakarta Islamic Index (JII) Di Bursa Efek Indonesia, Univesitas Muhammadiyah Surakarta

Karim, Adiwarman. 2008. Ekonomi Makro Islami, Jakarta: PT. Raja Grafindo Persada

Karlina, Kiki. 2017. Pengaruh Variabel Makro Ekonomi Terhadap Indeks Saham Syariah Indonesia (ISSI) di Bursa Efek Indonesia Periode Januari 2014-Juli 2016, Universitas Muhammadiyah Surakarta

Kontan.co.id, diakses pada tanggal 27 Maret 2019 pukul 18:39 WIB (https://investasi.kontan.co.id/news/efekperang-dagang-dan-bunga-the-fed-padasaham-domestik-hanya-sesaat) (https://keuangan.kontan.co.id/news/inidampak-kenaikan-suku-bunga-the-fed$\underline{\text { menurut-bankir) }}$

Manan, Abdul. 2012. Aspek Hukum Dalam Penyelenggaraan Investasi Di Pasar Modal Syariah Indonesia. Jakarta: Kencana
Mankiw, N. Gregory. 2002. Principle Of Economics, 3th edition, terjemahan Chriswan Sungkono, Salemba Empat, Jakarta

Mawarni, Citra Puspa, Anny Widiasmara. Oktober 2018. Pengaruh Fed Rate, Harga Minyak Dunia, BI Rate, Inflasi dan Kurs Rupiah Terhadap Indeks Saham Syariah Indonesia (ISSI) Periode Tahun 2011-2017, Jurnal Akuntansi, Prodi Akuntansi FEB UNIPMA, Vol. 2, No. 2

Miyanti, Gusti Ayu Diah Akua. 2018. Pengaruh Suku Bungan The FED, Harga Minyak dan Inflasi Terhadap Indeks Harga Gabungan (IHSG) di Bursa Efek Indonesia, EJournal Ekonomi dan Bisnis Universitas Udayana, ISSN: 2337-3067

Misgiyanti, Idah Zuhroh. Juli 2009. Pengaruh Suku Bunga Luar Negeri Federal Reserve (The FED), Nilai Tukar Rupiah/US \$ dan Inflasi Terhadap Indeks Harga Saham Gabungan di Bursa Efek Indonesia Periode 2006-2008, Jurnal Ekonomi Pembangunan, Vol. 7, No. 1

Moore, Geoffrey H. 1990. Gold Prices and a Leading Index of Inflation, Challenge, 33(4), pp. $52-56$

Muttaqin, Nur Imam. 2017. Pengaruh Kurs, Inflasi, Jumlah Uang Beredar, Suku Bunga Bank Indonesia, dan IHSG Terhadap Index Harga Saham Syariah di Jakarta Islamic Index (JII) Periode Januari 2011-Desember 2016, Universitas Muhammadiyah Surakarta

Otoritas Jasa Keuangan, diakses pada tanggal 27 Maret 2019 pukul 17:00 WIB (https://ojk.go.id/id/kanal/syariah/data-danstatistik/sahamsyariah/Documents/Pages/Statistik-SahamSyariah---Januari-2019/Statistik\%20Saham2019\%20Januari.pdf)

Pasaribu, Rowland Bismark Fernando. Juli 2013. Analisis Pengaruh Variabel Makro Ekonomi Terhadap Indeks Saham Syariah Indonesia, Jurnal Ekonomi dan Bisnis, Vol. 7, No. 2

Putri, Ovin Liliana. 2018. Analisa Pengaruh Faktor Makro Ekonomi Terhadap 
Indeks Saham Syariah Indonesia (ISSI), Skripsi: Universitas Islam Indonesia Yogyakarta

Rachmawati, Martien, Nisful Laila. November 2015. Faktor Makro Ekonomi Yang Mempengaruhi Pergerakan Harga Saham Pada Indeks Saham Syariah Indonesia (ISSI) di Bursa Efek Indonesia (BEI), JESTT, Vol. 2, No. 11

Samuelson, Paul A dan William D. Nordhaus. 2009. Economic, Nineteenth Edition, New York: Mc Graw-Hill Irwin

Saputra, Rega, Erdah Litriani. Juni 2017. Pengaruh BI Rate, Nilai Tukar Rupiah, dan Sertifikat Bank Indonesia Syariah (SBIS) Terhadap Indeks Saham Syariah Indonesia (ISSI), I-Economic, Vol. 3, No. 1

Sartika, Umi. Desember 2017. Pengaruh Inflasi, Tingkat Suku Bunga, Kurs, Harga Minyak Dunia dan Harga Emas Dunia Terhadap IHSG dan JII di Bursa Efek Indonesia. I-Finance, Vol. 3, No. 2

Suciningtias, Siti, Rizki Khoiroh. Mei 2015. Analisis Dampak Variabel Makro Ekonomi Terhadap Indeks Saham Syariah Indonesia (ISSI). $2^{\text {nd }}$ Conference In Business, Accounting, and Management. Universitas Islam Sultan Agung, ISSN 2302 - 9791. Vol 2, No. 1

Sudjono. 2002. Keseimbangan Hubungan Simultan Antara Variabel Ekonomi Makro Yaitu: Bunga Deposito, Bunga SBI, Jumlah Uang Beredar, Nilai Tukar Rupiah dan Inflasi Terhadap Index Harga Saham Di BEJ Dengan Metode VAR dan ECM. Jurnal Riset Ekonomi

Sunariyah, 2003. Pengantar Pengetahuan Pasar Modal. UPP AMP YKPN

Sutedi, Adrian. 2011. Pasar Modal Syariah: Sarana Investasi Keuangan Berdasarkan Prinsip Syariah. Jakarta: Sinar Grafika
Susyanti, Jeni. 2016. Pengelolaan Lembaga Keuangan Syariah. Malang: Intrans Publishing

Syahrir, 1995. Analisis Bursa Efek. Jakarta: PT. Gramedia Pustaka Utama

Syukma, Novia Handayani. 2011. Analisis Faktor-Faktor Makroekonomi Yang Mempengaruhi Return Saham Batubara Dalam Kelompok Jakarta Islamic Index (JII). Skripsi: Institut Pertanian Bogor

Tandelilin, Eduardus. 2010. Portofolio dan Investasi Teori dan Aplikasi, Edisi Pertama. Yogyakarta: Kanisius

Triswati, Fitria Irmi. Bank Indonesia: BI Rate Versus SBI Rate, https://rmol.co/read/2011/10/07/41691/ diakses pada 24 Maret 2019 pukul 17:22 WIB

Wahid, Abdul. 2018. Analisis Pengaruh Inflasi, Tingkat Suku Bunga, dan Harga Emas Dunia Terhadap Index Harga Saham di Jakarta Islamic Index (JII) Periode 2010-2015, Univesitas Muhammadiyah Surakarta

Wahyuningrum, Meylani. 2016. Analisis Faktor-Faktor Yang Mempengaruhi Indeks Saham Syariah Indonesia (ISSI), Universitas Muhammadiyah Surakarta

Wicaksono, Immanuel Satrio, Gerianta Wirawan Yasa. Januari 2017. Pengaruh FED Rate, Indeks Dow Jones, Nikkei 225, Hang Seng Terhadap Indeks Harga Saham Gabungan, E-Jurnal Akuntansi Universitas Udayana, Vol. 18, No. 1

Widyasa, Vitra Islami Ananda, Saparila Worokinasih. Juli 2018. Pengaruh Tingkat Inflasi, Nilai Tukar Rupiah, dan Tingkat Suku Bunga Domestik Terhadap Indeks Saham Syariah Indonesia (ISSI), Jurnal Admnistrasi Bisnis (JAB), Vol. 60, No. 1

Wijayaningsih, Ria, dkk. April 2016. Pengaruh BI Rate, FED Rate, dan Kurs Rupiah Terhadap Indeks Harga Saham Gabungan (IHSG), Jurnal Administrasi Bisnis (JAB), Vol. 33, No. 2 